Article

\title{
Religious Engagement and the Migration Issue: Towards Reconciling Political and Moral Duty
}

\author{
Joanna Kulska $\mathbb{D}$ \\ Institute of Political Science and Administration, University of Opole, Katowicka 89, 45-061 Opole, Poland; \\ jkulska@uni.opole.pl
}

Received: 31 March 2020; Accepted: 7 May 2020; Published: 11 May 2020

check for updates

\begin{abstract}
The increasingly acknowledged post-secular perspective has resulted in the emergence of some new approaches theorizing this phenomenon. One such approach has been the concept of religious engagement, which calls for the redefinition of the perception of religious non-state actors towards including them as important partners in the process of identifying and realizing political goals. According to this view, due to the multidimensional role played by religious communities and non-state religious actors, they need to be recognized as pivotal in creating a new form of knowledge generated through encounter and dialogue of the political decision-makers with these subjects. Among numerous others, the challenge of migration calls for enhanced debate referring to both political and ethical issues. When such a perspective is applied, the question is raised of the duties and limits of nation-states using more or less harsh political measures towards refugees and migrants based on the concept of security, but also short-term political goals. In the face of a state's lack of will or capacity to deal with the problem of migration, the question of religion serving not only as the service-provider but also as the "trend-setter" with regard to fundamental ethical questions needs to be considered.
\end{abstract}

Keywords: religious engagement; post-secularism; civil society; transformative approach; relational approach; duty dilemma; Humanitarian Corridors; Community of Sant'Egidio

\section{Introduction}

Out of many unexpected, yet decisive dimensions of religion's "come back" in the social-political arena over the last decades, both globally and locally, the revisited relation between "the secular" and "the religious", and as a result, "the political" and "the religious" has emerged. Against the tradition of strict separation of both spheres rooted in the Westphalian-Enlightenment tradition, increasingly visible bridging and even overlapping of both domains has been "discovered" or "rediscovered" (Berger 1999; Philpott 2002; Haynes 2007; Thomas 2005). Following Scott Appleby's ambivalence of religion (Appleby 2000), the "both and" approach referring to "religious and secular", substituting the old "either or" approach, has been postulated by many. Vendulka Kubálková proposes the overcoming of dualism and recognition of coexistence of religion and politics through political theology (Kubálková 2000). Marc Gopin speaks of negotiating religious and secular contributions to social change (Gopin 2015). Erin Wilson suggests relational dialogism (Wilson 2012). Slavica Jakelić conceptualizes secular-religious encounters as peacebuilding (Jakelić 2015).

The idea that the sacred can be part of the secular is one of the Durkheim's most radical and underappreciated claims regarding religion (Barnett 2015). Today, the very categories of the religious and the secular in the public sphere are being revisited, reworked, and rethought (Mendieta and VanAntwerpen 2011). The mentioned reconceptualization does not only refer to some specific areas of common interest in which secular and religious actors have cooperated, but it also applies to mutual recognition of the religious and secular domains as such in domestic and global politics. 
The expression of this recognition has been the influential concept of post-secularism which, though contested (Mavelli and Petito 2014), opens a new space for mutual appreciation and mutual inspiration (Haynes 2016). In the post-secular society, the liberal ethics of citizenship requires from both religious and secular citizens a "complementary learning process" (Habermas 2005). According to this approach, in the post-secular society, believers and non-believers "have cognitive reasons to take seriously each other's contributions to controversial subjects in the public debate" (Ratzinger and Habermas 2006).

Religious-political cooperation emerged first in such traditional crucial areas of religious and faith-based actors' activities as development and humanitarian aid. Soon, the kind of badly needed "symbiosis" was unveiled in the area of conflict resolution and peacebuilding (Johnston and Sampson 1994). As the concept of "peace" has been gradually reconceptualized and broadened, the religious and secular approaches found common ground stressing the relational and transformative dimensions of conflict resolution and peacebuilding (Galtung 2007; Lederach 1999). As a result, religious "thinking" as well an religious "doing" have to a certain extent been transferred to the domains that had been reserved earlier to political decision-makers and referred to as "high politics" (Seiple and Hoover 2004; Johnston 2003; Surmacz 2013). Contribution of religious and faith-based actors, constituting a crucial share of the civil society sector, has thus increasingly been perceived not only as a type of "first-aid", but also as a premise of reshaping the relationship of power and authority of the state in contemporary global politics (Wilson 2014). Eventually, based on the assertion of the critical role of the religious and faith-based actors in improving the level of comprehension and mutual understanding in an increasingly culturally pluralistic and politically fragmented global setting, the concept of religious engagement has been proposed (Appleby et al. 2010; Petito and Thomas 2015; Mandaville and Silvestri 2015).

According to the concept of religious engagement, the role of religious and faith-based non-state actors cannot be reduced to charity and humanitarian aid performed in the international arena. Due to their social but also political capacity, they have to be recognized as partners whose potential not only can, but in fact has to be, considered at the political-making level in the area of foreign policy. The essential contribution that religious communities and non-state actors can make is a new form of knowledge, which is generated through the encounter and dialogue with religious communities and religious actors. The approach is based on the assumption that in the contemporary world, knowledge is constructed from the bottom and not from the top, and thus the bottom layers of the society and not the top ones "can also be the preferential place for epistemology, for discovering what knowledge is, how it is constructed and in whose interests it is constructed" (Petito and Thomas 2015) in the area of global politics. As such, religion needs to also be understood as part of historical progress. The result of the emergence of a new secular-religious partnership is the stretching of political imagination and creating new practical innovations to respond to numerous global challenges (Petito and Thomas 2015; Petito 2019).

Although referring to the religious perspective has not (yet) become a universal pattern, it has gradually been included into the wider discourse in the context of growing significance of civil society initiatives and track II diplomacy. Additionally, within the framework of existing church-state relations in some states, religious and faith-based non-state actors have become, to a certain extent, representatives of track I diplomacy (Stensvold and Vik 2018). As Raffaele Marchetti rightly stresses, it is thus important not only to realize the increasing influence of the civil society actors on the country's foreign policy, but to also realize how foreign policy is increasingly made in the first person by the civil society actors themselves (Marchetti 2018).

The significance of religious contribution in the normative sense, but also through creating a specific set of proposals to the most challenging problems of the present era, has been well evidenced in the case of migration issues. When analyzing prospects of dealing with the problem of migration a decade ago, it was possible to state that the liberal state may choose to develop a systematic approach to the problem of immigration, which means it can come up with a view of what kind of people it wants to include or exclude, but it may also choose not to develop such an approach (Risse 2008). 
The second option no longer seems possible, which proves the dynamism of the situation as well the necessity of quick, innovative reaction. In the face of the increasing challenge of migration, some very harsh responses to the problem were applied in countries like the USA or Australia, as well as in some countries of the CEE region. The migrants were either rejected the possibility of entering the country under any conditions or they were, as in the case of the USA and Australia, directed to detention centers that provided heavily criticized standards of treatment. Finally, during Donald Trump's presidency, the procedure of separating the illegal immigrants from their children at the Mexican-American border was performed based on the "zero tolerance" policy (Foulkes 2012; Mittelstadt 2018). Meanwhile, the innovative measures rooted in the civil society initiatives have been introduced, constituting a valuable alternative in terms of ethical and political reaction to the drama of migration. As the examples of Australia and Italy show, religious communities and faith-based actors have always been actively involved in these responses. Using the concepts and practices consistent with faith-based hospitality they were able to challenge public discourse and to propose measures reflecting a wide, human-oriented perspective (Wilson 2011; Bernardo 2019).

In Italy, the project of Humanitarian Corridors introduced in 2015 by the group of civil society actors in agreement with the Italian government resulted in creating new channels of engagement and effective support for the most vulnerable ones within the existing legal framework. The solutions based on mobilization of the society and creating a big solidarity net have been recognized and appreciated at the governmental, European, and global level as the legal and safe resettlement of the asylum seekers. Although what religious and faith-based bodies have proposed and achieved in this regard cannot be perceived as an "all-encompassing" solution, they did effectively utilize their intellectual and material resources to creatively emphasize the ethical obligations of the government and the society (Rolando 2018).

The article is divided into three sections. The first one is focused on the theoretical analysis of the religious-political nexus and, more specifically, the concept of "religious engagement", which while referring to the area of foreign policy is also more or less directly affecting the domestic political developments in which religious and faith-based actors are engaged. In the second section, the religious and faith-based actors' role is discussed within the wider framework of the civil society sector regarding the evolution of mutual relations between the civil society sector and government. In this part, the issue of the specific placement and understanding of the concept of peace by the religious and faith-based actors is also considered. The third section deals with the problem of dialectics of migration perceived in the context of "duty dilemma" (Delsol 2016) between the political-cultural duty of the government to protect its population, territory, and cultural identity, and ethical duty to provide support to those whose lives are endangered.

In this paper, I propose looking at religious engagement through the prism of two major approaches developed in the religious context, especially Christianity, serving as the basic aim but also the instrument of constructing and reconstructing of the socio-political order, namely the relational and transformative approach. As the ordering remark, it needs to be emphasized that the project of Humanitarian Corridors discussed in the article has been selected due to its growing international visibility and effectiveness, as just one among numerous initiatives directed at supporting migrants undertaken by multiple faith-based actors.

\section{From "Missing Dimension" to "Religious Engagement": Reconceptualization of the Relations between Religion and Politics}

When looking from the historical perspective at the development of the new, post-Cold War understanding of mutual relations between religion and politics, the current moment may be regarded as an important point of reflection. A quarter of a century ago, in his milestone publication, former US diplomat and political scientist Douglas Johnston was calling for the change of the paradigm between religion and politics. According to his view, which turned out to be enormously influential for further developments: "The application of religious factors to political problems is inherently 
complex and fraught with peril; hence the Western predilection for maintaining a complete separation between the two. But the potential for overcoming the shortcomings of conventional diplomacy in some situations by introducing religious or spiritual factors appears to be substantial. It suggests that foreign policy professionals and religious practitioners should study the possibilities and seek to facilitate and reinforce one another's efforts to resolve conflict wherever it appears sensible to do so" (Johnston and Sampson 1994). In the book, referred to widely in the literature on the topic, Douglas Johnston thus focused not only on "bringing religion back", but also on building the area of common support, and even cooperation in the field of conflict resolution where religious factors simply cannot be overlooked. At the same time though he was calling for the profound change in the area of both domestic and foreign policy towards including the more holistic, more relational, and in fact more anthropocentric perspective taking into account also the non-state actors. "The challenge is to reach beyond the state-centric focus on power-politics model to accommodate non-governmental interactions at the subnational and individual level" (Johnston and Sampson 1994).

Since then, the long distance has been covered in terms of the empirically visible emergence of the religious factor in the area of global politics, in respect to gaining knowledge and understanding of this emergence, and finally in evolving a normative outlook on the role of religious resources in the public discourse. The significance of the topic, as well as its complexity, has been increasingly expressed through the growing epistemic community of activists, scholars, and policymakers recognizing that the religious factor can no longer be ignored (Bettiza 2019).

For both the policymakers and scholars, the crucial obstacle and challenge is the "form" of secularism that has dominated in the public space and in social science. The essence of this particular approach, which became decisive in the discourse, was the positioning of religion as the "enemy", and preventing any other type of more "friendly" outlook. Secularism in this pervasive version is not a neutral, objective theory trying to explain the direction of development of the reality, but its ideological, dogmatic, exclusivist vision that led to "secular bias". What has been analyzed and explained over the last decades is that the challenge of overcoming "old thinking" is even deeper when considering the "Westphalian synthesis" and influential Westphalian-Enlightenment prejudice, which introduced the mythologized, reductivist perspective of religion in the process of the development of the modern state system (Philpott 2000). As a consequence "blind spots" (Petito 2019) occurred, which can be summarized as not just "overseeing" the huge and meaningful dimension of objective reality, but forming the discourse based on the purposefully constructed vision of this reality based on "fairytales" (Thomas 2005), "legends" (Barnett 2015), and "myths" (Cavanaugh 2009).

As a reaction to this "ontological injustice" (Wilson 2017) first in the US and the UK, and later in continental Europe, considerable reconceptualization of the dominating secular perspective has been postulated. Soon, around the beginning of the new millennium, the breakthrough concept, the ambivalent role of religion in the socio-political reality has been proposed (Appleby 2000; Gopin 2000) and the field of the religious peacebuilding has emerged, first in the US and later in Europe (Hertog 2010). Almost at the same time, the notion of post-secularism has been developed (Habermas 2001), which contributed significantly to the redefinition of mutual relations between religion and politics. Finally, the far-reaching concept of religious engagement has been suggested (Appleby et al. 2010) and developed gradually, not only as a theoretical construct, but also as the element of the new institutionalized approach to religion (Petito and Thomas 2015; Mandaville and Silvestri 2015; Bettiza 2019; Petito 2019).

Out of many different empirical and theoretical consequences of "bringing religion back" and including it as a valuable partner in the search for the "common humanity", the "3D" perception could be proposed as the one summarizing the reconceptualization in terms of placement of the religious factor. They would be demythologization, dualism, and dialogue, simultaneously creating, as it seems, a coherent vision of the discussed reconceptualization. Demythologization would refer to both secularism and religious violence perceived so far as the main "option" for religious presence in the public sphere. Dualism would concern on the one hand "reaching beyond" and overcoming of the perception of religious and secular as separate spheres, but also understanding the dichotomic, 
ambivalent role of religion. It would lead to a new sensitivity about reality perceived so far as the neatly separated, closed domains of the meaning of "secular, rational and public" and "religious, irrational and private" (Wilson 2012). Through the overcoming of this exclusivist approach, the space for an inclusive, dialogical view could be constructed. Dialogue would mean in this regard creating the possibility of encountering both, so far separated spheres of the sacrum and the profanum.

Though the concept has been questioned and contested (Mavelli and Petito 2014), post-secularism did enable a new stage of discussion and facilitated a "new reading of reality". As Luca Mavelli and Fabio Petito notice: "The question raised by the post-secular ( . . ) is not just one of incorporation of the presence of religion or the power of secularism into existing theoretical frameworks, but one of the conceptual innovations to account for a transformation that invests the very structures of consciousness and power, and existing understandings of political community" (Mavelli and Petito 2014). When the post-secular perspective is recognized and included in the discourse on the evolution of contemporary world order, it allows for the assessment of the contemporary socio-political sphere as neither secular, nor linear, but transformative.

As a result of the "post-secular turn", post-secular consciousness and post-secular sensitivity have been created, which to a significant extent express themselves in the concept of religious engagement. This new perspective not only allows religion to be more present in the public sphere, but also sees religion and religious actors as the valuable resource in all the domains of socio-political reality as "religion's importance and relevance is more wide ranging than is indicated by limiting its presumed role to the impact of ideas on politics" (Petito and Thomas 2015). The crucial aspect here is the concept offered by Jürgen Habermas of approaching religion as the depositary of "normative intuition" and thus as the potential source of the "change" that occupies central place in the major religious doctrines (Gopin 2015; Gawerc 2006).

Religious engagement embodies all the crucial elements of this new perception of secular-religious nexus first championed by the constellation of civil society actors embedded in and responding to an emerging post-secular world society. The beginning of the process can be dated back to the early 1990s, with acceleration in the aftermath of $9 / 11$. At that time, the loosely knit epistemic community emerged among international affairs scholars and analysts in the US. This epistemic community, which became the carrier of post-secular consciousness, has developed two strategies of religious engagement. The first one, a narrower one and referring directly to the intellectual and practical contribution of Douglas Johnston, sees religion as the means of promoting world peace and security. The other one is more ambitious and more broadly recognizes religious contribution in terms of promoting international order and progress (Bettiza 2019).

The concept of religious engagement does not refer to the simple developing of good relations with religious and FBOs actors. The concept is to draw attention to the new ways in which governments can engage and partner with religious and faith-based non-state actors to deal with a wide spectrum of global policy issues and challenges. Crucial for the religious engagement is also understanding its prophetic potential. In this understanding, religious engagement is perceived through its ability to develop the new secular-religious partnership, stretching the political imagination and creating practical innovations to respond to global policy challenges (Petito 2019).

The perspective of religious engagement, understood as a religious-secular partnership, brings the profound reconceptualization of how the Western, and more specifically Eurocentric civilization, has been oriented in terms of the limited lens of perceiving and understanding of the social-political constellation of today. The deliberations on understanding of such crucial concepts as progress or inclusion of the other (Buber 1992, 1993; Lévinas 1994; Tischner 1998) have been the ever-present issue in the human reflection. What is currently happening in this regard should be perceived as one of the important dimensions of the transformation of the normative structure of international society, beyond its Eurocentric civilizational origin as well as liberal ideological configuration (Petito 2019). With the less self-centered, more pluralist, more inclusive, and more dialogue-oriented perspective, more options are "on the table" in the increasingly challenging socio-political post-secular reality. 
In the post-secular discourse, the wide definition of politics is referred to. This definition encompasses state-based politics and policies, but also dominant ideological visions that shape those policies and influence the narratives of the broader civil society and public sphere. Such a perspective brings recognition of the non-state religious actors as those who affect the understanding of power through contesting its source and meaning, but at the same time contribute to perceiving it through the prism of relationships (May et al. 2014). In this context, politics is about relationships, and active citizens are the ones who increasingly contribute to broadening of comprehension of how politics should be understood and how it should be performed (Saunders 2005).

\section{FBOs: Bridging Religious Engagement and Religious Peacebuilding}

The perspectives that post-secularism and religious engagement offer are multifold and multidirectional. They enable bridging, for the two-sided benefit, the non-religious and religious spheres as the ones mutually supporting, purifying, and improving one another (Ratzinger and Habermas 2006). The argument is raised in this regard on the irreplaceable role of religion in the public sphere, where religious actors are often capable of discovering hidden institutions or recreating lost elements of meaning and identity. According to the post-secular outlook, they profitably use modes of reasoning different from the public reason (Kratochvil 2009). On the other hand, from the side of the religious perspective, the argument is raised that the reason can only function well when it is enlightened by the light of faith (Mazurkiewicz 2012).

As political scientist Jeffrey Haynes rightly notes, one of the most visible signs of post-secularism has been the increasing presence of non-state religious actors at the level of civil society, both within and between the states. The decisive explanatory factor was the demise of optimism about the perceived "superiority" of rational secular values and the " (.. ) growing willingness to accept that maybe, after all, "religion" might have something to tell us about how to run international relations better, that is ideas and values stemming from religious beliefs might conceivably assist in states' developing cooperation and undermining chances of conflict, while helping to provide an ethical framework for improved international collaboration" (Haynes 2014).

The mutual relations between religion and civil society have been profoundly analyzed and well known in the literature of the subject (Casanova 2005; Berger 2003; Wilson 2014; Herbert 2003). As fundamentally belonging to the civil society sector, religions have increasingly been present in the public sphere joining the voices of contestation against the state and the market economy (Casanova 2005). In activating civil structures, religions play a few fundamental functions. Firstly, they mobilize modern societies to the collective and public reflection on the normative issues, and introduce their own arguments on the controversial problems. Secondly, they stress the principle of the common good and the community of the moral issues constituting the challenge against the individualist-liberal theories, which reduce the common good to the sum of the personal preferences. Finally, religions address the principle of solidarity with all the people emphasizing the superiority of the dignity of a human person over the dominating systems of the state power and capitalist market (Szymczak 2015).

Both the discourses and the practices of global political and economic liberalism not only enable but even necessitate FBOs' growth and spreading of scope of their activities, especially after the end of the Cold War and in conjunction with the retreat of the state (Lynch 2011). They contribute to building social cohesion, social capital, both bridging and bonding one (Putnam 2001) and "salvation" of civil society as such (Bretherton 2010). As the actors of the civil society belong neither to the state nor to the market, religious and faith-based actors may be seen as mediating structures and the expression of the people's empowerment (Berger and Neuhaus 1996). In this role, they are part of the process through which the individuals negotiate, argue, struggle against, and agree with each other and with the centers of political and economic authority (Kaldor 2003).

Religion is both much more and much less than meets the eye (Barnett 2015). Religious and faith-based actors play not only a corrective (Mazurkiewicz 2012), but also an innovative role. In the process of the discussed reconceptualization of the relation between the secular and the political, 
religious and faith-based bodies have not only emerged as the "first-aid" providers, but also as the source of alternative proposals towards how the complex challenges in the domestic and international scale should be approached. As such, they have been actively engaged in political campaigning and advocacy work, and in promoting an alternative political and ethical paradigm based on which policies can be developed and implemented (Wilson 2014). In the face of retreat of the state and the need for alternative proposals regarding numerous new problems that are unveiled in the socio-political reality, religious considerations are often arising as not one of many, but the main or the only resource to refer to. As a result, their contributions are becoming increasingly visible and recognized as the element of developing "ethical imagination" and "ethical capacity" at the civil society level, both locally and globally. At the same time, though oriented towards the transcendence, the focus of faith-based actors is very much anthropocentric and oriented towards introducing the change in the social-political dimension, and is thus transformative.

FBOs function in a multi-dimensional manner in terms of engaging society. On the one hand, they are directed at the outside environment, meaning those in any kind of need for material and non-material support. Acting as such, they influence the political sphere both as the service providers and as the "idea providers". On the other hand, they are directed at their "internal environment", which means expressing certain values and attitudes based on their moral orientations and commitments. In fact, in the case of transnational FBOs, the differentiation into the "internal" and "external" environment is difficult to define. As such, they become "cosmopolitan" and gain the possibility of transferring the local innovations to the national and global level. What needs to be stressed in this regard is their flexibility and, in a majority of cases, the capacity of adjusting to the socio-political reality. Theologies constantly evolve to cope with the changing political conditions, liberalizing economies and the links between individual and communal rights and practices (Lynch 2011).

Both a narrow and broad understanding of the concept of religious engagement are more or less linked to the issue of peace being the most fundamental, yet the most unrealized human need (Ramsbotham et al. 2011). Peace is the major goal and commitment of all the major religious doctrines, as well as underlying purpose of the political communities (Cortright 2008). Holistically, anthropologically understood peace should be thus perceived as the most fundamental framework for religious-political partnership. What needs be focused on as the area of overlapping and mutual inspiration is the notion of positive, just peace and not the negative peace, meaning the absence of conflict. Present in the religious doctrines since ancient times, with the Book of Isaiah being its most well-known example, the broadly understood concept of positive, just peace has been transferred into the secular domain. Peace has thus been increasingly recognized in the relational and transformative dimension (Galtung 2007; Lederach 1999).

The "father" of Peace (and Conflict) Studies Johan Galtung notices that the good start for discussion on the relations between religion and peace could be the word "religion" itself. As re-ligio can be interpreted as the relinking in the language of social science, this would mean some kind of integration (Galtung 2016). In the search for a dialogical approach to the problems of war and peace, religions could become the "joint human property" in the rapidly globalizing world (Galtung and MacQueen 2008). With their comprehension of conflict, religions may be perceived as the "ingenious" source of knowledge on how to solve it and as the "reservoirs of wisdom" (Gopin 2015).

The area of the "religious-political nexus" as the general framework for partnership embraces "thinking about peace" and "making peace", but also concepts such as "positive peace" and "just peace", as well as crucial from both the religious and secular perspective "transformation of the conflict" aiming at reconciliation. The innovative peace-oriented, relational, and transformative approaches engaging religious actors have been conceptualized with terms such as "relational diplomacy", "diplomacy of friendship", "faith-based diplomacy", and finally as the concept encompassing all the particular ones, namely religious peacebuilding (Hertog 2010).

Characterized by a high level of interdisciplinarity, religious peacebuilding is defined as the range of activities performed by religious actors and institutions for the purpose of resolving and 
transforming conflicts with the goal of building social relations and political institutions, characterized by an ethos of tolerance and nonviolence (Little and Appleby 2004). Being the crucial though rarely discussed and analyzed dimension of the "return of religion", religious peacebuilding implies reaching to the peaceful sources of the different religions in the doctrinal and ethical sense, which translates into multilevel activities undertaken by the religious and faith-based actors. At the same time, referring to the ever-existing links between religion and politics, religious peacebuilding can be perceived as the increasingly institutionalized dimension of the mutual interactions between sacrum and profanum (May et al. 2014).

Both in the theoretical and in the empirical sphere, religious peacebuilding has gained the status of the bridge between activities undertaken by religious and non-religious actors in the area of conflict resolution and peacebuilding. The meaningful symptom of this phenomenon has been the occurrence in the political and politological discourse of religiously rooted, "non-political" concepts such as reconciliation, guilt, or forgiveness. Along with them, such crucial notions as "positive peace" and "just peace", and also "brotherhood", "friendship", "love", and "hope" are more extensively discussed as the elements of an alternative approach to conflict resolution and peacebuilding, but also to politics as such (Kulska 2019).

As peace is a relation between parties, building peace means improving relations. In the relational approach the security concept will not be helpful. Since according to this view, some party is perceived as a threat to be deterred or eliminated, there is no focus on improving relations. To achieve peace, the transformation of relations is needed, which requires the transcending of goals of the parties and creating a new reality based on empathy, non-violence, and creative thinking (Galtung 1996, 2007). The desired outcome of this transformation is reconciliation (Lederach 1999). In this process, "the other" is de-demonized and rehumanized.

\section{Dialectics of Migration as a Political and Ethical Problem}

As peace is the value in the international reality, it is an ethical problem (Kuźniar 1991). The spreading of peace is the moral imperative at the level of individuals, institutions, and states regardless of their geopolitical location. At the same time, "ethics is born when "the other" enters the scene" (Eco and Martini 2019). "The other" means thus "the obligation" for those referring to some kind of transcendence and those not having such a point of reference. This is also the moment when politics comes in with its defining of "the other" for its own purposes and using its own political measures. While referring to distinct kinds of reasoning, the religious and non-religious overlap with reference to the fundamental human dignity (Solarz 2012).

The other is created to define the "borders". The defining ones are the governments and the societies. The process is dependent on numerous political, cultural, social, and economic determinants. But the final outcomes in this process of defining who "the other" is and what political measures to use while deciding on "the other's" image and political-cultural responsibility, can be influenced by non-political arguments and attitudes. This matters especially when realist, state-interest, and conflict-oriented political views are involved. States are the ones that do not always have the will or capacity to spread the message of peace (Egeland 2013). However, they do have to define themselves in terms of the relation towards "the other".

Dialectical relations towards "the other" can be detected when the etymology of both the term "guest" and "hospitality" is analyzed. In ancient times, on the one hand, the word guest meant someone who would be welcome and awaited and whose coming implied certain obligations on the side of the state. On the other hand the term was referred as "the other", or the enemy. This resulted in stretching the term between acceptance and affections and hatred or open enmity. From the very beginning, the term also resulted in some social and political consequences as "hospitality" was linked to unselfish care of the guest and at the same time deeply rooted in the ruler-serf dependence (Pisarek 2010).

From both the theoretical and practical point of view, migration has always been a dialectical phenomenon. This dialectic has unveiled itself both in the social-cultural and political dimension. 
For ages, migrations have been characterized by two co-existing phenomena. Although they meant the development and the enrichment of both the hosts and the hosted ones, they raised the issue of troublesome identity, exclusion, and fear. "The other" has thus been the instrument utilized by the those holding power to exercise their power in accordance to the immortal divide et impera and evoking the sense of fear, but also constituted the premise for mobilization at the social level to reach out to those marginalized ones (Kulska 2018).

What has grown to the extent of an enormous political challenge over the last decades has been the clash between ethics and politics with reference to "duty dilemma" in the context of migration issues, and especially the problem of refugees. The political and cultural obligation of the government is to protect the population not only in the sense of territory, but also safeguard the culture which the given population recognizes as its fatherland. In this regard, the government is authorized not to allow the refugees to enter, even if this violates the moral obligation towards those in need. When looking from the moral perspective, the view is different as the society has the moral obligation towards those who are in need, even if this would undermine the cultural identity of the hosting country (Delsol 2016). Simultaneously, the most subtle dilemma in politics occurs specifically within the dilemma of choosing of the lesser evil (Grosfeld 2010).

The migration issue invokes the eternal question of the relations between politics and morality on a universal scale. Assessment of debates upon the political limits of migration is essential to understand the evolving conditions and determinants of the contemporary politics. Out of many social-political challenges that governments have to face, migration appears to be one of the most complex and most challenging ones. The problem of migration could be perceived as the lens through which all the major dilemmas of the relation between the individual, the society, and the state focus. Refugees reveal a deep contradiction in contemporary patterns of political sovereignty. The issues of migration and asylum bring to the fore the question about relations between identity, citizenship, and the rule of law (Bretherton 2010). Among them, there is the inclusion-exclusion issue, and in this context, there is not only the "politics of identity" problem, but also the "politics of fear" problem (Fukuyama 2019). The crucial challenge, not just legal but also moral, is assessing illegal immigration and asking ourselves as citizens, but also as humans, are the illegal migrants actually doing something wrong? There is no doubt they are breaking the law but arguably, from a moral standpoint, not all methods of breaking the law are to be condemned (Risse 2008).

When describing the struggle between duty and morality, Darwin stresses that the instinct of sympathy or empathy constitutes the most noble part of human nature and that the highest moral achievement is concern for the welfare of all living beings, both human and nonhuman (Ekman 2010). This statement, though not referring directly to the sphere of politics, carries an enormous political weight. You cannot create a good citizen unless one is a good person (Mazurkiewicz 2007). Though defining the term of a good man is not an easy task, one might, following Darwin, risk the statement that definitely empathy is important component of the man referred to as "good". The crucial issue is how to foster this instinct of empathy in the society. The question belongs to the category of the fundamental ones, not just in relation to the problem of "defining the borders". The matter seems to be of pivotal importance also in the perspective of social cohesion and social capital and the conditions of functioning in the society deprived of empathy towards any, both internal and external, "the other" (Nussbaum 2015).

Religion is the most, or at least one of the most, effective cultural practices defining the individuals and the communities. It helps to determine, implement, and authorize what is good, what is evil, what is right, and what is wrong (Petito and Thomas 2015). At the same time, religions, particularly those with formal institutional structures, are one of the few means of mobilizing people for common, public action. As such, they provide an opportunity to move beyond politics perceived through the prism of legal and market proceduralism but, what's even more challenging "they keep alive ultimate questions about what it means to be human and what a good life consists of in such a way as to re-open the need for political deliberation about what we value and why we value it" (Bretherton 2010). 
In the conditions of the deliberative democracy, the state does not have a monopoly in defining the social and cultural borders of "moral imagination" and "ethical capacity". What is essential in this regard is the engagement of the civil society and its role in shaping the image of the other and the attitudes towards "the other". The religious voice can be regarded as important and useful for achieving "social sensitivity" resulting from "bringing up" the society and developing the awareness and compassion towards those more vulnerable. The specific dimension of "knowledge creation", but also "relationship creation" in the conditions of the post-secular society can be recognized as the pivotal responsibility on the side of the religious and faith-based actors.

Encounter, dialogue, and knowledge are the elements of religious engagement, and all embrace different dimensions of inclusion and recognition of the value of religious contribution. Following cognitive and communicative aspects of partnership between religion and politics, relational and transformative aspects occur. These aspects, both in the conceptual and operational sense, are embodied at two main levels. The first of them is the level of civil society, where the non-state religious and faith-based bodies address their activities at the subjects, both individual and collective ones, directly with no involvement of the state. But there is also the second possibility of addressing their activities as the actors of the civil society sector with the involvement of the governmental level. While an increase in the level of "overlapping" of the religious and secular activities increasingly raises the questions of the "healthy limits" of such a cooperation at the same time it offers new horizons of potential innovations to which the religious actors can contribute. As an element of the public discourse, this could also refer to the dialogue between the state and the active, participating citizens whose contribution may mean "added value" to the governments' activities (Saunders 2005).

The relationship between the governments and the civil society organizations (CSOs) should not be conceived as being unidirectional, where either CSOs influence the state or the state co-opts the CSOs being predominant. "The relationship is rather of mutual synergy effectively improving the political capacity of both actors". In the process of practical accomplishment of the project, both sides can benefit from each other's "channels of access" that both sides possess. While CSOs need to rely on government actors to access diplomatic negotiation channels, governments can benefit from the indirect support offered by the CSOs. Among the most important dimensions of such support, apart from offering technical skills and infrastructural resources, generating awareness and public support in the countries to be persuaded are of crucial importance (Marchetti 2018).

Migration, both as a political and an ethical problem, has always been a part of human history and a topic of both secular and religious reflection. At the present moment, migration is one of the key reasons for the emerging of post-secular society. According to the new post-secular perspective, religious communities need to be perceived as the "communities of interpretation" irrespective of whether religion occurs in their case as the stabilizing or destabilizing factor. On the other hand, the "post-secular consciousness" is created, which provides the opportunity to see "the other" from two perspectives. The "other" is the one who should be recognized and included as the subject that has the right to preserve identity and the mode of life (Kratochvil 2009). At the same time though, "the other" is the one that has something to offer the hosting community. The potential of offering some assets lies also on the side of the religious communities occurring in the role of providers of specific, more spiritual, but also practically oriented on the "the other" views and attitudes. They find their expression in the ethics of hospitality, which finds its roots both in the secular and religious reflection (Baker 2011; Wilson 2011).

\section{Humanitarian Corridors: From Fear to Empathy}

For the Christian organizations, the central concepts are charity, philanthropy, volunteering, and the notion of civil society (Bernardo 2019). They offer a very concrete, doctrinally embedded vision of how the problem of migration should be perceived. Faith-based hospitality is rooted in the theological arguments concerning the dignity and sacredness of every human being and commitment to follow the example of Christ (Wilson 2011), whose teachings introduced the revolutionary change in the 
perception of the relationship towards "the other", transcending the "rule of law" towards the "rule of love". As Leszek Kołakowski points out, Jesus' teachings were the challenge to the world from which the new universe has emerged. The essence of transformation that he proposed was love. The key issue, though, was that this transformation was not imposed from the position of the one holding power. His message was based on the force that changes the soul and makes it ready to follow the certain path (Kołakowski 2014). Love and compassion hold the center and require a fullness of commitment (Lederach 2014).

As such, Christ's calling "I was a stranger and you took me in" (Mt, 25, 35) is moral encouragement for the voluntary "reaction of heart", but also the call for responsibility for a transforming of the world that became the pattern for activities addressed towards those displaced ones. Yet in the Christian approach, not only the teachings but also the story of Jesus himself is the fundamental point of reference emphasized by the fact the entirety of Jesus's personal experience is one of a refugee (Montville 2016). "Jesus lived in a war zone under foreign military occupation in a period of civil war and violent insurgency against the foreign occupier and the domestic leaders who cooperated with the occupying forces. He and his family were refugees, according to the definition of the 1951 Convention on Refugees; they fled genocide, as described in the 1948 Convention for the Prevention and Punishment of the Crime of Genocide" (Cusimano Love 2015).

In the documents of numerous European Christian Churches referring to the migration issue "God is a God on the move whom we can meet in the stranger". They underline the necessity of building the "culture of welcome" and the "culture of encounter" in the spirit of solidarity and universal community based on human fraternity in spite of all the difficulties that opening to others entails. Christian cosmopolitanism can be perceived as an alternative to overly-protectionist visions of the nation-state in addition to the abstract accounts of liberal cosmopolitanism that calls for borderless states (Bretherton 2010). At the same time, the religiously rooted concept of just peace critiques, complements, and supplements the liberal peace (Omer 2015). Contrary to reducing the hospitality only to charity (Baker 2011), just peace criteria include a participatory process, the right relationships, restoration, reconciliation, and sustainability (Cusimano Love 2015). In the area of migration, just peace means, first of all, the relational and transformative dimension aimed at building the new reality both for the hosted ones and the hosts.

The establishment of "deep, serious and intense bonds between those who organize the project and the beneficiaries" (Rolando 2018) has been one the priorities of Humanitarian Corridors. The project has served as the ground-breaking solution proposed by a group of Christian actors to deal with the migration problem after its drastic increase in 2015. The concept of Humanitarian Corridors, which became the exemplification of religious engagement first in the relation with the Italian government, and later some other European countries, constituted not only some legal option directed at those putting their lives at risk while trying to cross the Mediterranean Sea. It also showed the small-scale, yet epochal alternative, towards the governments and the societies struggling to respond to this axiological and normative challenge to solve the "duty dilemma". As such, Humanitarian Corridors became both ethically and politically acceptable ways to reconcile between the political-cultural demand to protect the population and moral obligation to reach out to "the other".

Three crucial actors were engaged in the introduction and realization of the project: The Waldensian Church, the Federation of Protestant Church, and the Catholic Community of Sant'Egidio. The concept and procedures consisted of a few stages. The main role for the start of the project was played by Waldensian Church, which made available the capital for the initial phase of the project based on the "eight per thousand", which means $0.8 \%$ of the annual tax received from the state of Italy. Later, the original sponsors were joined by others, including private individuals, societies, cooperatives, labor unions, and other religious communities that consisted of particularly Jewish and Asian communities (Rolando 2018). What was created was a big solidarity net and a peculiar form of "ecumenism in action" (Bernardo 2019). 
The legal mechanism of the project is based on Article 25 of the Schengen regulations, which allows a state to release humanitarian visas in order to allow the vulnerable people to be exceptionally granted access to the country. After the mechanism was developed conceptually, it was proposed to the Italian Ministry of Foreign and International Affairs. As a result, the memorandum of understanding was signed in December 2015 and renewed in November 2017. It envisaged bringing into Italy up to 1000 asylum seekers per cycle in a safe and legal fashion.

Three main objectives were aimed for in the project. Firstly, it was making the arrival to Italy safe and legal. Secondly, it helped the refugees to overcome trauma that all of them experienced in a majority of forms. At this stage, it was also important to make them understand how they might imagine their new lives in Italy. Thirdly, it helped them to find a job and eventually to become independent. In the process, two standards were applied, which were avoiding the concentration of the newcomers in one location and engaging the local communities to take part in the reception. Those accompanying the refugees are thus not professional social workers, but usually volunteers concentrated around the church or the parish (Rolando 2018).

One of the actors that has participated within the project and soon has become the "face" of the initiative is Community of Sant'Egidio. In this way it followed its 50-year-long tradition of developing the unique model of lay vocation (Johnston 2008). Through its original interpretation of the Christian message, an innovative and effective community constitutes one of the most compelling examples of transcending existing visions and practices in the area of religious engagement. Established in 1968 by a group of high school students under the leadership of Andrea Riccardi with the purpose to practically perform the premises of the Second Vatican Council, it refers to five pillars: Prayer, evangelization, solidarity with the poor, ecumenism, and dialogue (Community of Sant'Egidio 2020).

The essence of Community's goals is expressed in the 3P concept, meaning prayer, poor, and peace. Following this framework, Community has become one of the most well-known bodies advocating for the poor and marginalized ones, but also the successful mediator and facilitator in the area of religious peacemaking. As such, Community has been engaged in numerous global campaigns dealing with AIDS or the death-penalty, and also in coordinating the World Day of Prayer for Peace in Assisi, initiated by John Paul II in 1986, which brings yearly representatives of numerous different religions. Even though the members carry out their work of service on a strictly volunteer basis, and they use virtually no paid staff, Community has been able to make a substantial difference in the places where it operates. On the local scale, this means running soup kitchens and small group homes for the elderly and AIDS patients, and providing numerous services to immigrants and refugees. On the larger scale, it means advocacy on a number of issues such as the rights of the elderly and immigrants or the global campaign against the death penalty (Johnston 2008).

Community has been well-known for successfully brokering the peace negotiations that led to ending the bloody war in Mozambique (Albright 2007) as well as in numerous other conflicts over the last decades. In fact though these activities have been perceived through the lens of service to the poor. Andrea Riccardi emphasizes that Community's orientation towards faith and evangelical inspiration are at the heart of its existence, and its main and fundamental identity is "first and foremost a Christian community" (Riccardi 2013). Known as the "U.N. of Trastevere", Community of Sant'Egidio's self-understanding has relatively little to do with diplomatic work: "Rather, Sant'Edigio is primarily a community of lay people who try to live the gospel through a life of prayer and service to the poor" (Johnston 2008).

While encounter and dialogue are the main aspects of the concept of religious engagement, they are also the essence of the Sant'Egidio's theoretical and practical alignment. Encounter means to "encounter with real people" and dialogue "is ingrained in the DNA of the Community". Peace is achieved through dialogue, search for common good, mediation, and agreement, which are the determinants of developing human relationships (Riccardi 2013). Equally important is not just bearing "witness" to the moral or religious value of peace, but acting in practice to achieve it. Present only in the sphere of hopes and dreams, peace may be practically achieved when its vision is internalized. This 
capacity to dream in reality should be perceived as one of the main Community's sources of success. What it entails is transformation of perception of reality in such a way that the inability to envision the peaceful, undivided future is altered with the new hopeful alternative that reaches beyond the existing options (Riccardi 2013; Johnston 2008).

The constituting framework organizing Community's universal vision based on the hope for change is a vision of overcoming indifference and building a more human world where there will be a place for everyone (Pope Francis 2017). The core of the image of a peaceful, just world is fundamentally expressed in the vision of "the other". Being the central focus in the spirituality of Community's perception of the other has been significantly shaped by the theological influence of one of the most important theologians of the XX century and the participant of the Second Vatican Council French theologian Yves Congar. According to Congar, the key moral test for Christians who would be engaged in the world is their attitude towards "the other". In his perception, true dialogue, which is the foundation for the church's relations to the world, depends on the ability to accept "the other" as other, and the willingness to be open to what "the other" can teach us (Johnston 2008). Thus, the notion of dialogue is not the normative concept, but the base for the members of the Community to practically, on a daily basis, open themselves up to developing relations of friendship with those encountered ones. This particular concept of true opening to "the other", building the real, direct relations based on patient communication has become the unique instrument worked out the Community known as "diplomacy of friendship" (Giro 2000).

"To be holy is the world" has been the essence of Community's spirituality and practice (Johnston 2008). Based on the conviction that responsibility and ability to act rely upon ordinary people, the citizens, Community is orienting itself towards the demanding, innovative initiatives through which it creates its own, specific mode of "knowledge" utilized in numerous projects realized both in Italy and abroad. Deeply rooted in the spirit of the Second Vatican Council and the influence made by Ives Congar, it strongly refers to his vision of constructing the Church through new, different forms of fulfilling the Gospel without betraying its truth and its tradition, the forms of holiness less opposed to the earthly life. As such, it operates towards recognizing the reality beyond the existing constraints. This mode brings together some elements of visionary idealism but, at the same time, pragmatism based of the experience gained during the years of its multidimensional service to "the other" based on the premise that no people are strangers, especially not those experiencing suffering (Johnston 2008; Riccardi 2013).

Community has been engaged in helping migrants since the 1970s when they started to be a significant component of the Italian society. Since then, the two main objectives have been organizing practical support in receiving and integrating migrants. In 1982, Community organized the first language course for immigrants, perceiving the knowledge of Italian as the "access key" to integration. Soon, the branches of the School of Language and Culture were established in numerous Italian and European cities, creating this way the "high-impact generators of inclusion". At the end of 1980s, the movement called the People of Peace was established, which is supported by the Community as the place for creating the culture of "peaceful and sympathetic citizenship" among the people of different ethnic and religious origins.

Since 2015, over 2400 refugees were safely relocated in Italy with the support of local organizations, parishes, and the people of good will (Del Re 2019). Even though the scale of the Humanitarian Corridors project is not big, and definitely not sufficient compared to the scale of needs, it was a "small step to remove the brick from the wall" (Gois and Falchi 2017) that did create first the "domino effect" and later the "spill over effect". Following Italy, the agreements on establishing the Humanitarian Corridors were signed in the subsequent years with France, Belgium, and Germany (PAP 2019). Later, the pattern was transferred into the global discourse, becoming the "show case" in terms of new solutions for asylum seekers. As such, the project was discussed as one of the proposals for the Global Compact on Refugees, which was a non-binding international agreement that was adopted by more than 180 states in December 2018. The document, which was approved after two years of extensive consultations led 
by UNHCR with Member States, international organizations, refugees, civil society, the private sector, and experts, is to serve as a framework for more equitable responsibility-sharing. It not only recognizes that a sustainable solution to the problem cannot be achieved without international cooperation. In fact, it calls for the transformation of the image of refugees, showing their presence as an advantage to the communities that host them (United Nations 2018). In the statement at Global Refugee Forum one year later, Emanuela Del Re, Minister of International Cooperation for Italy, pointed out that "Italy has never lost the sense of its moral responsibility towards women and men in need" and that "Every person counts". She also stressed that Italy proposed the model of Humanitarian Corridors at the European Parliament as a pattern to become a European practice in the form of European Humanitarian Corridors (Del Re 2019). In 2019, Humanitarian Corridors, as the complementary pathway to existing third country resettlement programs, has been recognized by UNHCR as a "ground-breaking cross-border initiative". As such, UNHCR has named the project as regional winner of the prestigious Nansen Refugee Award (Patisson 2019). The agency praised the scheme as a "lifeline for those at greatest risk" and an urgently needed pathway for protection (Higgins 2019).

The Italian case of cooperation between the religious and faith-based actors can be perceived as an example of the intense effective synergy that has been established between the Italian government and the organizations of the Italian civil society. Looking from the perspective of gains on the side of the government, the long-time cooperation between civil society actors and the government has made it possible for Italy to take a leading role at the international level, moving from rule-taking to rule-making (Marchetti 2018).

The concept of Humanitarian Corridors constituted the visionary, engaged response to probably the most dramatic and most pressing humanitarian issues of the last decades. In this process, thanks to the religious perspective, the important innovation has been proposed. This innovation, based on knowledge coming from encounter and dialogue, served both as the purpose and as the instrument of relational and transformative approaches to problem of migration. The project of Humanitarian Corridors shows that religious contribution should be recognized at many different levels which, to a certain extent, serves as the role-model of what religious and faith-based organization can offer as the "added value". As a type of "bottom up" project, fully organized and financed by the civil society, it created the solidarity net that became the message to the politicians and to the societies raising their knowledge of "the other" and the sense of empathy which is the condition of proper functioning of the society. This way, the receiving societies and the governments become themselves the beneficiaries of the project, not only at the intercultural, cognitive, and communication level, but also through the prism of "emotional capacity" and "ethical imagination", contributing to development of civic participation, engagement, and responsibility (Safjan 2018).

\section{Conclusions}

Over the last three decades, many religiously rooted ideas and institutions have been effectively developed and applied as the result of a secular-religious partnership. While reaching the doctrinal and ethical fundaments, they often transcended the existing notions constituting the source for the further mutual inspiration. Among them, there are such fundamental concepts as reconciliation, just peace, relational diplomacy, or transformation of conflict. Along with other socio-political problems where the non-state religious and faith-based actors turned out to be indispensable, there has also been the issue of migration.

The religious and non-state actors have long been involved in providing humanitarian aid to the displaced person. However, in the face of the scale and nature of the migration wave that Europe has been struggling with since 2015, their engagement gained a new innovatory form and a new dimension. As such, the issue of migration has become one of the main areas where not just the "technical solutions" but the ethical dimension as well has to be recognized, thus constituting the vast area of creating "common knowledge" on contemporary political challenges. In this process, 
the "reinclusion" and "reappreciation" of the religious dimension turned out to be an indispensable option for political deliberations.

The project of Humanitarian Corridors can be perceived as the exemplification of the religious-political partnership in which policy is not only significantly influenced, but in fact made in the first person by civil society actors themselves. Since 2015, the project carried by the Waldensian Church, the Federation of Protestant Churches, and the Community of Sant'Egidio served as a successful innovation and a case of multi-stakeholder engagement not only to the most vulnerable refugees, who were offered legal and safe resettlement, but also the involved governments and the European societies struggling with the "duty dilemma" between the political and moral obligations towards "the other". As such, the project can be perceived as the pioneering case of civil society mobilization not against but with the government, as well as the instrument of creating of civic culture recognizing "the other" not as inferior, but as equally important and vulnerable. In this process, the religiously rooted perspective of re-humanization against dehumanization was applied, which is the essence of the relational and transformative approach in the area of religious conflict transformation and peacebuilding.

Ethics is born when "the other" enters the scene. While obviously acts of altruism are not reserved solely to those referring to some religious foundations, civil society initiatives expressed in the form of the Humanitarian Corridors can be perceived as the demanding call aimed at raising the ethical awareness and fundamental empathy on the side of society, as well as offering a legal and politically acceptable solution to the government. As a result, "multi-sided" advantageous political- religious partnership has been constructed. It expresses itself in the "concentric triad" of those "empowered" in the process, meaning the migrants, civil society actors, and the government.

Among the numerous advantages of the project, the essence of the "empowerment" could be reduced to fundamental significance of rudimentary moral considerations. In a way, the explanation for those activities at the motivational level can be recapitulated in the two main ideas referred to by the actors engaged in Humanitarian Corridors, both on the non-governmental side. "Every person counts" (Del Re 2019) and "A few small drops can change the sea" (Gois and Falchi 2017) could be well used as the evidence of the already achieved level of mutual understanding and stimulus between the religious and the political. The human being is not only homo politicus, but also homo religiosus and homo esperans. The sharpened perspective on this multidimensionality of the individual combining all those equally important aspects of "human condition" has been better understood, respected, and acknowledged.

Ethics, which according to Kant means the relation towards what is the absolute good, introduces dynamism in the social life (Mazurkiewicz 2007). Religious-secular partnership becomes the source of the dynamic progress at both the political and human level. Reinclusion, reinterpretation, and reappreciation of the religious voice creates a new "window of opportunity" (Mendieta and VanAntwerpen 2011), which can be constructively utilized for advancing the ever-present challenge of defining and constructing of "common good" and "common humanity".

Funding: This research received no external funding.

Conflicts of Interest: The author declares no conflict of interest.

\section{References}

Albright, Madeleine. 2007. The Mighty and the Almighty. Reflections on America, God, and World Affairs. New York: Harper Perennial.

Appleby, Scott R. 2000. The Ambivalence of the Sacred: Religion, Violence and Reconciliation. Lanham: Rowman \& Littlefield Publishers.

Appleby, Scott R., Richard Cizik, and Thomas Wright. 2010. Engaging Religious Communities Abroad: A New Imperative for U.S. Foreign Policy. Chicago: Chicago Council of Global Affairs.

Baker, Gideon. 2011. Politicizing Ethics in International Relations: Cosmopolitanism as Hospitality. New York: Routledge. 
Barnett, Michael. 2015. Religion and the Liberal International Order. In Faith, Freedom and Foreign Policy. Challenges for the Transatlantic Community. Edited by Michael Barnett, Clifford Bob, Nora Fisher Onar, Anne Jenichen, Michael Leigh and Lucian N. Leustean. Washington: Transatlantic Academy, pp. 8-29.

Berger, Peter L. 1999. The Desecularization of the World: A Global Overview. In The Desecularization of the World: Resurgent Religion and World Politics. Edited by Peter L. Berger. Washington: Ethics and Public Policy Center, pp. 1-18.

Berger, Julia. 2003. Religious Non-Governmental Organizations: An Explanatory Analysis. Voluntas: International Journal of Voluntary and Non-Profit Organizations 14: 15-39. [CrossRef]

Berger, Peter L., and Richard L. Neuhaus. 1996. To Empower People: From State to Civil Society. Washington: AEI Press.

Bernardo, Angela. 2019. Communicating Religion in the Age of Emergency. In Mediterraneo. Tradizione, Patrimonio, Prospettive. Una Proposta per L'innovazione e lo Sviluppo. Edited by Alberto Aghemo and Rosella Pace. Roma: Fondazione Giacomo Matteotti, pp. 255-73.

Bettiza, Gregorio. 2019. Finding Faith in Foreign Policy. Religion and American Diplomacy in a Postsecular World. New York: Oxford University Press.

Bretherton, Luke. 2010. Christianity and Contemporary Politics. The Conditions and Possibilities of Faithful Witness. Chichester: Blackwell Publishing. [CrossRef]

Buber, Martin. 1992. Ja i Ty. Wybór pism Filozoficznych. Warszawa: Instytut Wydawniczy Pax.

Buber, Martin. 1993. Problem Człowieka. Warszawa: Spacja.

Casanova, José. 2005. Religie Publiczne w Nowoczesnym Świecie. Kraków: Zakład Wydawniczy Nomos.

Cavanaugh, William T. 2009. The Myth of Religious Violence: Secular Ideology and the Roots of Modern Conflict. New York: Oxford University Press.

Community of Sant'Egidio. 2020. Available online: http://www.santegidio.org/pageID/2/langID/en/theCommunity.html (accessed on 29 March 2020).

Cortright, David. 2008. Peace: A History of Movements and Ideas. New York: Cambridge University Press.

Cusimano Love, Mayann. 2015. Building a Better Peace: A Future Worthy of Our Faith. Available online: https://www.americamagazine.org/issue/building-better-peace (accessed on 18 March 2020).

Del Re, Emanuela. 2019. Statement by Hon. Emanuela Der Re, Minister for International Cooperation If Italy at the Global Refugee Forum. December 17. Available online: https://www.unhcr.org/en-au/events/conferences/ $5 \mathrm{df8f6fd4/statement-from-italy.html?query=humanitarian \% 20corridors} \mathrm{(accessed} \mathrm{on} 14$ March 2020).

Delsol, Chantal. 2016. Wielkie migracje a przyszłość Europy. Chrześcijaństwo-Świat-Polityka 20: 9-14. [CrossRef]

Eco, Umberto, and Carlo Maria Martini. 2019. Gdy na scenę wkracza inny, rodzi się etyka. Available online: https://www.przewodnik-katolicki.pl/Archiwum/2019/Przewodnik-Katolicki-38-2019/ Temat-numeru/Gdy-na-scene-wkracza-inny-rodzi-sie-etyka (accessed on 16 March 2020).

Egeland, Jan. 2013. Humanitarian diplomacy. In The Oxford Handbook of Modern Diplomacy. Edited by Andrew F. Cooper, Jorge Heine and Ramesh Thukur. New York: Oxford University Press.

Ekman, Paul. 2010. Darwin's compassionate view of human nature. JAMA 303: 557-58. [CrossRef] [PubMed]

Foulkes, Christopher D. 2012. Australia's Boat People: Asylum Challenges and Two Decades of Policy Experimentation. Available online: https://www.migrationpolicy.org/article/australias-boat-people-asylumchallenges-and-two-decades-policy-experimentation (accessed on 5 May 2020).

Fukuyama, Francis. 2019. Tożsamość. Współczesna polityka tożsamościowa i walka o uznanie. Poznań: Dom Wydawniczy Rebis.

Galtung, Johan. 1996. Peace by Peaceful Means: Peace and Conflict, Development and Civilization. Oslo: Peace Research Institute.

Galtung, Johan. 2007. Peace by Peaceful Conflict Transformation-The TRANSCENDENT Approach. In Handbook of Peace and Conflict Studies. Edited by Charles Webel and Johan Galtung. New York: Routledge, pp. 14-32.

Galtung, Johan. 2016. Religions Hard and Soft. In The Ashgate Research Companion to Religion and Conflict Resolution. Edited by Lee Marsden. New York: Routledge, pp. 247-63.

Galtung, Johan, and Graeme MacQueen. 2008. Globalizing God-Religion, Spirituality and Peace. Grenzlach-Whylen: Transcend University Press.

Gawerc, Michelle. 2006. Peace-building. Theoretical and Concrete Perspectives. Peace \& Change 31: 435-64.

Giro, Mario. 2000. Sant'Egidio's diplomacy of friendship. The UNESCO Courier 53: 33-34. 
Gois, Pedro, and Giulia Falchi. 2017. The third way. Humanitarian corridors in Peacetime as a (local) civil society response to EU's common failure. REMHU: Revista Interdisciplinar da Mobilidade Humana 51: 59-75. [CrossRef]

Gopin, Marc. 2000. Between Eden and Armageddon. The Future of World Religions, Violence and Peacemaking. New York: Oxford University Press.

Gopin, Marc. 2015. Negotiating Secular and Religious Contributions to Social Change and Peacebuilding. In The Oxford Handbook of Religion, Conflict and Peacebuilding. Edited by Atalia Omer, R. Scott Appleby and David Little. New York: Oxford University Press.

Grosfeld, Jan. 2010. Kilka uwag o losie chrześcijanina w polityce. Chrześcijaństwo-Świat-Polityka 11: 4-7.

Habermas, Jürgen. 2001. Glauben und Wissen. Frankfurt: Suhrkamp Verlag.

Habermas, Jürgen. 2005. Religion in the Public Sphere. Lecture Presented at the Holberg Prize Seminar. November 29. Available online: https://holbergprisen.no/sites/default/files/Habermas_religion_in_the_ public_sphere.pdf (accessed on 16 March 2020).

Haynes, Jeffrey. 2007. An Introduction to International Relations and Religion. London: Routledge.

Haynes, Jeffrey. 2014. Faith-Based Organizations at the European Union and United Nations: From Marginalization to Significance. In Towards a Postsecular International Politics: New Forms of Community, Identity and Power. Edited by Luca Mavelli and Fabio Petito. New York: Palgrave Macmillan.

Haynes, Jeffrey. 2016. Religious Transnational Actors and Soft Power. New York: Routledge.

Herbert, David. 2003. Religion and Civil Society: Rethinking Religion in the Contemporary World. New York: Routledge.

Hertog, Katrin. 2010. The Complex Reality of Religious Peacebuilding: Conceptual Contributions and Critical Analysis. Lanham: Lexington Books.

Higgins, Claire. 2019. Corridors of Hope: What One Italian "Life-Line" Delivers? Available online: https://www.kaldorcentre.unsw.edu.au/news/corridors-hope-what-one-italian-\%E2\%80\%98lifeline $\%$ E2\%80\%99-delivers (accessed on 10 March 2020).

Jakelić, Slavica. 2015. Secular-Religious Encounters as Peacebuilding. In The Oxford Handbook of Religion, Conflict and Peacebuilding. Edited by Atalia Omer, R. Scott Appleby and David Little. New York: Oxford University Press.

Johnston, Douglas. 2003. Faith-Based Diplomacy. Trumping Realpolitik. New York: Oxford University Press.

Johnston, Laurie. 2008. "To be Holy in the World". The Influence of Yves Congar on the Spirituality and Practice of the Community of Sant'Egidio. In Catholic Identity and the Laity. Edited by Tim Muldoon. New York: Orbis Books.

Johnston, Douglas, and Cynthia Sampson. 1994. Religion, the Missing Dimension of Statecraft. New York: Oxford University Press.

Kaldor, Mary. 2003. The Idea of Global Civil Society. International Affairs 79: 583-93. [CrossRef]

Kołakowski, Leszek. 2014. Jezus Ośmieszony. Esej Apologetyczny i Sceptyczny. Kraków: Wydawnictwo Znak.

Kratochvil, Petr. 2009. The Religious-Political Nexus in East-Central Europe: Church in the Public Sphere of Post-Secular Societies. Perspectives 17: 119-38.

Kubálková, Vendulka. 2000. Towards an International Political Theology. Millenium: Journal of International Studies 29: 675-704. [CrossRef]

Kulska, Joanna. 2018. Faith-based Organizations and the migration issue. In Social, Cultural, Ethical and Political Aspects of Migration. Edited by Tomáš Hubalék, Gabriela Cingelová, David Hampl, Zoltán Huszár, Pavel Kopeček, Pavel Krákora, Joanna Kulska, Marcel Lincényi, Zsolt Nemeskéri, Zdenka Nováková and et al. Bammental: Bettina Weiss Verlag, pp. 57-75.

Kulska, Joanna. 2019. Między Sacrum i Profanum. Rola Czynnika Religijnego w Rozwiązywaniu Konfliktów i Budowaniu Pokoju. Opole: Wydawnictwo Uniwersytetu Opolskiego.

Kuźniar, Roman. 1991. Etyczne pojmowanie pokoju. In Pokój w Teorii i Praktyce Stosunków Międzynarodowych. Edited by Józef Kukułka. Warszawa: Wydawnictwa Uniwersytetu Warszawskiego.

Lederach, John Paul. 1999. Building Peace: Sustainable Reconciliation in Divided Societies. Washington: United States Institute of Peace.

Lederach, John Paul. 2014. Reconcile. Conflict Transformation for Ordinary Christians. Kitchener: Herald Press.

Lévinas, Emmanuel. 1994. O Bogu, który Nawiedza myśl. Kraków: Wydawnictwo Znak. 
Little, David, and R. Scott Appleby. 2004. A Moment of Opportunity? The Promise of Religious Peacebuilding in an Era of Religious and Ethnic Conflict. In Religions and Peacebuilding. Edited by Harold Coward and Gordon S. Smith. New York: State University of New York Press, pp. 1-26.

Lynch, Cecylia. 2011. Religious Humanitarianism and the Global Politics of Secularism. In Rethinking Secularism. Edited by Craig Calhoun, Mark Juergensmeyer and Jonathan VanAntwerpen. New York: Oxford University Press.

Mandaville, Peter, and Sarah Silvestri. 2015. Integrating Religious Engagement into Diplomacy: Challenges \& Opportunities. Issues in Governance Studies 67: 1-13.

Marchetti, Raffaele. 2018. Italian hybrid diplomacy. Contemporary Italian Politics 10: 193-207. [CrossRef]

Mavelli, Luca, and Fabio Petito. 2014. Towards a Postsecular International Politics. New Forms of Community, Identity, and Power. New York: Palgrave Macmillan.

May, Samantha, Erin K. Wilson, Claudia Baumart-Ochse, and Faiz Sheikh. 2014. The Religious as Political and the Political as Religious: Globalisation, Post-secularism and the Shifting Boundaries of the Sacred. Politics, Ideology and Religion 15: 331-46. [CrossRef]

Mazurkiewicz, Piotr. 2007. Polityka-eschatologia-etyka. Chrześcijaństwo-Świat-Polityka 3: 29-32.

Mazurkiewicz, Piotr. 2012. Niepolityczna polityczność Kościoła. Chrześcijaństwo-Świat-Polityka 14: 5-20. [CrossRef]

Mendieta, Eduardo, and Jonathan VanAntwerpen. 2011. The Power of Religion in the Public Sphere. In The Power of Religion in the Public Sphere. Edited by Judith Butler, Jürgen Habermas, Charles Taylor and Cornel West. New York: Columbia University Press.

Mittelstadt, Michelle. 2018. Children on the Frontlines. Available online: https://www.migrationpolicy.org/article/ top-10-2018-issue-no-4-children-frontlines (accessed on 5 May 2020).

Montville, Joseph. 2016. The Moral Ties within the Family of Abraham: A Primer on Shared Social Values in Judaism, Christianity, and Islam. Journal of Ecumenical Studies 51: 245-56. [CrossRef]

Nussbaum, Martha. 2015. Political Emotions. Why Love Matters for Justice. Cambridge: Harvard University Press.

Omer, Atalia. 2015. Religion, Conflict and Peacebuilding: Synthetic Remarks. In The Oxford Handbook of Religion, Conflict and Peacebuilding. Edited by Atalia Omer, R. Scott Appleby and David Little. New York: Oxford University Press.

PAP. 2019. Ważny Dokument. Szef MSZ podpisał umowę z jedną z największych organizacji charytatywnych. Available online: https://www.polskieradio24.pl/5/1222/Artykul/2381438,Wazny-dokument-Szef-MSZpodpisal-umowe-z-jedna-z-najwiekszych-organizacji-charytatywnych (accessed on 16 March 2020).

Patisson, Stephen. 2019. UNHCR Names Nansen Refugee Award Regional Winners. Available online: https://www.unhcr.org/news/latest/2019/9/5d7a4f264/unhcr-names-nansen-refugee-award-regionalwinners.html (accessed on 15 March 2020).

Petito, Fabio. 2019. Religious Engagement in International Relations: Overcoming secular blind spots and building a postsecular sensitivity in foreign policy. Paper presented at the International Conference Secularism as a Challenge for Politics and Political Science, Warsaw, Poland, December 12-13.

Petito, Fabio, and Scott M. Thomas. 2015. Encounter, Dialogue, and Knowledge: Italy as a Special Case of Religious Engagement in Foreign Policy. The Review of Faith and International Affairs 13: 40-51. [CrossRef]

Philpott, Daniel. 2000. The Religious Roots of Modern International Relations. World Politics 54: 206-45. [CrossRef]

Philpott, Daniel. 2002. The Challenge of September 11 to Secularism in International Relations. World Politics 55: 66-95. [CrossRef]

Pisarek, Adam. 2010. Przekroczyć gościnność. O granicach domu i państwa. Anthropos? 14-15: 27-32. Available online: http://www.anthropos.us.edu.pl/anthropos8/texty/pisarek.htm (accessed on 22 March 2010).

Pope Francis. 2017. The Message for the First World Day of the Poor: Let Us Love Not with Words but with Deeds. Available online: http://www.vatican.va/content/francesco/en/messages/poveri/documents/papa-francesco_ 20170613_messaggio-i-giornatamondiale-poveri-2017.html (accessed on 30 March 2020).

Putnam, Robert. 2001. Bowling alone. The Collapse and Revival of American Community. New York: Simon \& Schuster Paperbacks.

Ramsbotham, Oliver, Tom Woodhouse, and Hugh Miall. 2011. Contemporary Conflict Resolution: The Prevention, Management and Transformation of Deadly Conflicts. Cambridge: Polity Press.

Ratzinger, Joseph, and Jürgen Habermas. 2006. The Dialectics of Secularization: On Reason and Religion. San Francisco: Ignatius Press. 
Riccardi, Andrea. 2013. Introduction. In Making Peace: The Role Played by the Community of Sant'Egidio in the International Arena. Edited by Roberto Morozzo della Rocca. London: New City.

Risse, Mathias. 2008. On the Morality of Immigration. Ethics E International Affairs 22: 25-33. Available online: https://www.carnegiecouncil.org/publications/journal/22_1/essays/001 (accessed on 12 March 2020).

Rolando, Francesco. 2018. Humanitarian Corridors to Italy. An Interview with Professor Paolo Naso. Harvard International Review 39: 64-67.

Safjan, Marek. 2018. Społeczeństwo obywatelskie w czasach kryzysu. Chrześcijaństwo-Świat-Polityka 22: 57-72. [CrossRef]

Saunders, Harold H. 2005. Politics Is about Relationships: A Blueprint for the Citizen's Century. New York: Palgrave Macmillan.

Seiple, Robert A., and Dennis R. Hoover. 2004. Religion and Security. The New Nexus in International Relations. Lanham: Rowman \& Littlefield Publishers.

Solarz, Anna M. 2012. Prymat prawa i moralności-Dziedzictwo myśli chrześcijańskiego średniowiecza we współczesnych stosunkach międzynarodowych. In Religia w Stosunkach Międzynarodowych. Edited by Anna M. Solarz and Hanna Schreiber. Warszawa: Wydawnictwa Uniwersytetu Warszawskiego.

Stensvold, Anne, and Ingrid Vik. 2018. Religious Peacemakers on the International Scene: Hopes and Motivations. The Review of Faith and International Affairs 16: 9-22. [CrossRef]

Surmacz, Beata. 2013. Kto jest dziś dyplomatą? In Nowe oblicza dyplomacji. Lublin: Wydawnictwo UMCS.

Szymczak, Wioletta. 2015. Społeczeństwo obywatelskie a religia. Typy relacji w perspektywie wiodących teorii socjologii religii. Roczniki Nauk Społecznych 2: 49-75. [CrossRef]

Thomas, Scott M. 2005. The Global Resurgence of Religion and the Transformation of International Relations: The Struggle for the Soul of the Twenty-First Century. New York: Palgrave Macmillan.

Tischner, Józef. 1998. Filozofia dramatu. Kraków: Znak.

United Nations. 2018. Report of the United Nations High Commissioner for Refugees. Part II. Global Compact on Refugees. New York: United Nations, Available online: https:/www.unhcr.org/gcr/GCR_English.pdf (accessed on 22 March 2020).

Wilson, Erin K. 2011. Much to Be Proud of, Much to be Done: Faith-Based Organizations and the Politics of Asylum in Australia. Journal of Refugee Studies 24: 548-64. [CrossRef]

Wilson, Erin K. 2012. After Secularism. Rethinking Religion in Global Politics. New York: Palgrave Macmillan.

Wilson, Erin K. 2014. Faith-Based Organizations and Postsecularism in Contemporary International Relations. In Towards a Postsecular International Politics: New Forms of Community, Identity and Power. Edited by Luca Mavelli and Fabio Petito. New York: Palgrave Macmillan.

Wilson, Erin K. 2017. "Power Differences" and "the Power of Difference". The Dominance of Secularism as Ontological Injustice. Globalizations 14: 1076-93. [CrossRef] 